\title{
KUAT TEKAN MORTAR GEOPOLIMER ABU TERBANG HYBRID MENGGUNAKAN SEMEN PORTLAND
}

\author{
Miguel Felix Wijaya ${ }^{1}$, Monita Olivia ${ }^{2 *}$, Edy Saputra ${ }^{3}$ \\ 1,2,3 Program Studi S1 Teknik Sipil, Fakultas Teknik, Universitas Riau \\ Kampus Bina Widya Jalan HR Soebrantas KM 12,5 Pekanbaru, Kode Pos 28293 \\ Email: miguel.felixwijaya@student.unri.ac.id , *monitaolivia@lecturer.unri.ac.id (corresponding author), \\ edysaputra_eng@yahoo.com
}

\begin{abstract}
ABSTRAK
Geopolimer hybrid dibuat dengan mengaktifkan abu terbang menggunakan alkali aktivator dan semen Portland sebagai bahan pengganti sebagian abu terbang untuk perawatan pada suhu ruang. Penelitian ini betujuan untuk mengkaji kuat tekan mortar geopolimer abu terbang hybrid dengan menggunakan semen Portland, yaitu OPC (Ordinary Portland Cement) dan PCC (Portland Composite Cement). Prosedur penelitian dimulai dengan pengujian karakteristik material yang digunakan, yaitu abu terbang dan agregat halus. Abu terbang PLTU Ombilin, Padang yang digunakan. Sedangkan, agregat halus Teratak Buluh, Kampar yang digunakan. Larutan alkali aktivator yang digunakan $\mathrm{NaOH} 10 \mathrm{M}$ dan 12M dengan rasio modulus aktivator (Ms) 1,5 dan 2,5. Persentase penggantian abu terbang dengan semen yang digunakan adalah $10 \%$ dan $15 \%$. Benda uji berupa mortar berbentuk kubus berukuran $5 \times 5 \times 5 \mathrm{~cm}$. Pengujian yang dilakukan adalah uji kuat tekan. Uji kuat tekan dilakukan setelah mortar berumur 7 hari dan 28 hari perawatan suhu ruang. Hasil pengujian menunjukkan kuat tekan tertinggi pada mortar geopolimer abu terbang hybrid dengan variasi $\mathrm{NaOH} 10 \mathrm{M}$, Ms 2,5 dan penggantian sebagian abu terbang dengan semen sebesar $15 \%$ pada umur 7 hari dan 28 hari perawatan suhu ruang, yaitu sebesar 8,27 MPa dan 13,33 MPa menggunakan OPC. Sedangkan, mortar geopolimer abu terbang hybrid menggunakan PCC pada umur 7 hari dan 28 hari, yaitu sebesar 6,27 MPa dan 11,47 MPa. Berdasarkan hasil pengujian tersebut dapat disimpulkan bahwa mortar geopolimer abu terbang hybrid menggunakan OPC memiliki kuat tekan yang lebih tinggi dibandingkan menggunakan PCC dari umur 7 hari hingga 28 hari perawatan suhu ruang.
\end{abstract}

Kata Kunci: Abu terbang, geopolimer hybrid, kuat tekan, mortar, semen Portland

\begin{abstract}
Geopolymer hybrid was made by activating fly ash with alkaline activator and Portland cement for replacing fly ash to accelerate curing in ambient temperature. This study aims to examine the compressive strength of geopolymer hybrid mortar using Portland cement, that is OPC (Ordinary Portland Cement) and PCC (Portland Composite Cement). The research procedure began with test the characteristics of the material used, that is fly ash and fine aggregate. The fly ash came from the Ombilin PLTU, Padang. Meanwhile, the fine aggregates came from Teratak Buluh, Kampar. Alkaline activator solutions used were $10 \mathrm{M}$ and $12 \mathrm{M} \mathrm{NaOH}$, modulus activator ratio (Ms) 1.5 and 2.5. The percentage of replacement of fly ash with cement used is $10 \%$ and $15 \%$. The size of the mold used was the cube of $5 \times 5 \times 5 \mathrm{~cm}$. Tests carried out include the mortar compressive strength test. Compressive strength testing was carried out at 7 days and 28 days of curing in ambient temperature. From the test results obtained the optimum compressive strength on geopolymer hybrid mortar was the variation of $10 \mathrm{M} \mathrm{NaOH}, 2.5$ and $15 \%$ replacement of fly ash with cement at 7 days and 28 days curing in ambient temperature by $8.27 \mathrm{MPa}$ and $13.33 \mathrm{MPa}$ used OPC. Meanwhile, geopolymer hybrid mortar used PCC at 7 days and 28 days by $6.27 \mathrm{MPa}$ and $11.47 \mathrm{MPa}$. Based on the results, the geopolymer hybrid mortar using OPC has higher compressive strength than using PCC at 7 days to 28 days curing in ambient temperature.
\end{abstract}

Keywords: Fly ash, geopolymer hybrid, compressive strength, mortar, Portland cement 


\section{PENDAHULUAN}

Abu terbang adalah limbah B3 (Bahan Berbahaya dan Beracun) sisa pembakaran batu bara yang berpotensi mencemari lingkungan karena mengandung logam berat berdasarkan Peraturan Pemerintah No 101 Tahun 2014 [1]. Indonesia adalah negara penghasil batu bara dengan jumlah produksi mencapai sebesar 218 juta ton pada tahun 2016 [2]. Pembakaran batu bara menghasilkan $5 \%$ polutan abu padat dengan sekitar $80-90 \%$ total jumlah abu terbang, $10-20 \%$ sisanya berupa abu dasar. Pengelolaan limbah hasil produksi secara tepat perlu dilakukan untuk menghindari pencemaran lingkungan.

Salah satu cara terbaik untuk menanggulangi limbah abu terbang adalah memanfaatkan abu terbang sebagai campuran beton. Berdasarkan ASTM C-618 2005 [3], abu terbang bersifat pozolanik yang membuat abu terbang cocok digunakan sebagai alternatif pengganti semen ke dalam campuran beton ataupun mortar. Selain itu, penggantian semen dengan abu terbang dapat mengurangi efek yang ditimbulkan dari produksi semen [4]. Semen Portland yang diproduksi menghasilkan gas $\mathrm{CO}_{2}$ (karbon dioksida) yang dilepaskan ke atmosfer sehingga menyebabkan pemanasan global. Oleh karena itu, limbah abu terbang dapat dimanfaatkan dalam campuran geopolimer yang dibuat tanpa semen menggunakan larutan alkali aktivator.

Joseph Dovidovits [5] mengembangkan sebuah penelitian material alternatif pengganti semen yang disebut dengan geopolimer. Bahan utama dari geopolimer adalah limbah hasil industri yang mengandung banyak silika dan alumina. Pengaktifan kedua senyawa tersebut menggunakan larutan aktivator seperti $\mathrm{NaOH}$ (sodium hidroksida) dan $\mathrm{Na}_{2} \mathrm{SiO}_{3}$ (sodium silikat). Perkembangan penelitian geopolimer sebagai bahan konstruksi alternatif secara umum masih memiliki kendala dalam pengaplikasian. Penelitian Habert et al. [6] menunjukkan beton geopolimer harus menggunakan perawatan suhu tinggi untuk mempercepat polimerisasi dan meningkatkan kekuatan. Akan tetapi, sulit untuk menggunakannya dalam pembuatan langsung di lapangan [7].

Penelitian Mejía et al. [8] menunjukkan ada bahan geopolimer jenis baru yang telah dikembangkan untuk mengatasi masalah tersebut. Geopolimer tersebut dikenal dengan geopolimer hybrid, yaitu mengkombinasikan geopolimer dengan bahan lain yang mengandung kalsium seperti OPC (Ordinary Portland Cement) untuk membantu perawatan pada suhu ruang. Geopolimer hybrid dibuat dengan proporsi semen Portland 20-30\%, dan proporsi abu terbang 60-70\%. Penelitian yang dilakukan García-lodeiro et al. [9] menunjukkan terjadi peningkatan kekuatan dan pengurangan porositas geopolimer yang dicampur dengan OPC pada perawatan suhu ruang. Hal tersebut membuktikan bahwa penggunaan OPC membantu ikatan polimerisasi yang lebih cepat sehingga meningkatkan kekuatan pada perawatan suhu ruang.

Tujuan dari penelitian ini adalah mengkaji karakteristik kimia abu terbang PLTU Ombilin Padang, mengkaji karakteristik agregat halus Sungai Teratak Buluh, Kampar, dan menganalisis kuat tekan mortar geopolimer abu terbang hybrid menggunakan semen Portland, yaitu OPC (Ordinary Portland Cement) dan PCC (Portland Composite Cement) serta membandingkan kuat tekan kedua mortar geopolimer abu terbang hybrid.

\section{TINJAUAN PUSTAKA}

\subsection{Mortar}

Mortar dibuat dari beberapa material meliputi semen, agregat halus dan air [10]. Kegunaan mortar adalah untuk menambah lekatan pada bagian konstruksi tertentu lainnya. Ukuran mortar adalah kubus kecil dengan dimensi sisi $5 \times 5 \times 5 \mathrm{~cm}$. Spesifikasi mortar dibagi menjadi empat tipe yang dapat dilihat pada Tabel 1 berikut.

Tabel 1. Spesifikasi Mortar [10]

\begin{tabular}{ccl}
\hline $\begin{array}{c}\text { Tipe } \\
\text { Mortar }\end{array}$ & $\begin{array}{c}\text { Kuat Tekan } \\
\text { Minimum }\end{array}$ & \multicolumn{1}{c}{ Aplikasi } \\
\hline $\begin{array}{c}\text { Mortar } \\
\text { tipe M }\end{array}$ & $\begin{array}{c}\text { 17,2 Mpa } \\
\text { (kuat tekan } \\
\text { tinggi) }\end{array}$ & $\begin{array}{l}\text { 1. Dinding dekat tanah } \\
\text { 2. Adukan pipa air kotor } \\
\text { 3. Adukan dinding penahan } \\
\text { tanah } \\
\text { 4. Adukan untuk jalan }\end{array}$ \\
\hline $\begin{array}{c}\text { Mortar } \\
\text { tipe S }\end{array}$ & $\begin{array}{c}\text { 12,4 Mpa } \\
\text { sedang) }\end{array}$ & $\begin{array}{l}\text { Diperlukan untuk daya rekat } \\
\text { tinggi dan adanya gaya } \\
\text { samping }\end{array}$ \\
\hline $\begin{array}{c}\text { Mortar } \\
\text { tipe N }\end{array}$ & $\begin{array}{l}\text { 5,2 Mpa (kuat } \\
\text { tekan rendah) }\end{array}$ & $\begin{array}{l}\text { Untuk pasangan dinding } \\
\text { yang tidak menahan beban } \\
\text { mengenai kekuatan }\end{array}$ \\
\hline $\begin{array}{c}\text { Mortar } \\
\text { tipe O }\end{array}$ & $\begin{array}{l}\text { 2,5 Mpa (kuat } \\
\text { tekan rendah) }\end{array}$ & $\begin{array}{l}\text { Untuk konstruksi dinding } \\
\text { yang tidak menahan beban } \\
\text { berat dan pengaruh cuaca } \\
\text { ringan }\end{array}$ \\
\hline
\end{tabular}

\subsection{Geopolimer Abu Terbang}

Geopolimer merupakan material polimerisasi yang disintesa dari bahan silika dan alumina yang tahan terhadap suhu tinggi dapat digunakan sebagai material anti kebakaran. Mortar geopolimer dibuat dengan campuran antara agregat halus, air dan bahan pengikat tanpa semen yang dihasilkan dari reaksi polimerisasi antara alkali aktivator seperti $\mathrm{NaOH}$ (sodium hidroksida) dan $\mathrm{Na}_{2} \mathrm{SiO}_{3}$ (sodium silikat) dengan limbah abu terbang yang mengandung silika dan alumina [11].

Tahap reaksi larutan alkali aktivator dengan abu terbang dijelaskan oleh Fernandez-Jimenez et al. [12] dapat dilihat pada Gambar 1. Tahap awal pemutusan partikel abu terbang oleh ion hidroksida $\mathrm{OH}$ - serta proses pengikatan polimerisasi. Pemutusan partikel abu terbang dimulai dengan reaksi kimia ion $\mathrm{OH}$ - dari larutan alkali aktivator ke permukaan abu terbang. Reaksi berlanjut ke bagian dalam dan menuju keluar atau sebaliknya secara bersamaan hingga seluruh abu terbang bereaksi. Reaksi dari alkali aktivator berlanjut hingga bagian partikel terkecil. Namun, juga terjadi terbentuknya lapisan penghambat dari bulatan-bulatan kecil yang tidak bereaksi dengan alkali. Pada tahap akhir akan terbentuk susunan geopolimer hasil reaksi dari abu terbang secara sempurna, 
hanya sebagian dari partikel abu terbang yang tidak bereaksi.

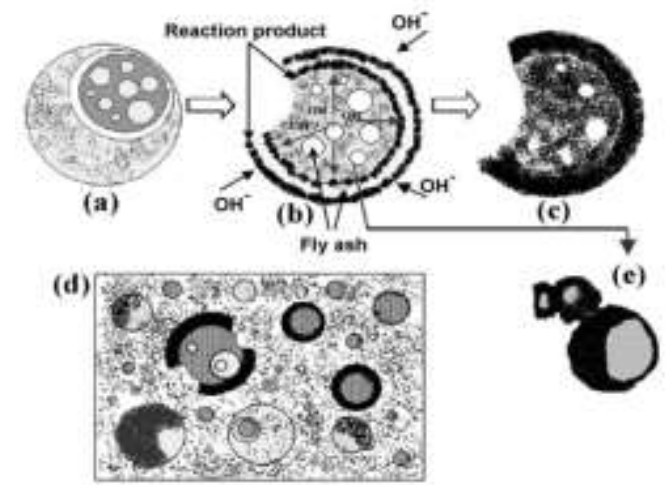

Gambar 1. Tahap Reaksi Larutan Alkali Aktivator dengan Abu Terbang [12]

Tahap ikatan polimerik yang terjadi pada geopolimer adalah reaksi unsur dari alkali aktivator dengan mineral silika dan aluminina sehingga menghasilkan rantai ikatan struktur O-Si-Al-O (O-T-O) yang konsisten [5]. Davidovits membagi polysialate menjadi tiga golongan, yaitu: poly(sialate) tipe (Si-O-Al$\mathrm{O})$, poly(sialate-siloxo) tipe (Si-O-Al-O-Si-O) dan poly(sialate-disiloxo) tipe (Si-O-Al-O-Si-O-Si-O) dapat dilihat pada Gambar 2 berikut.

\section{Poly(sialate) \\ (-Si-O-Al-O-)}

Poly(sialate-siloxo) (-Si-O-Al-O-Si-O-)

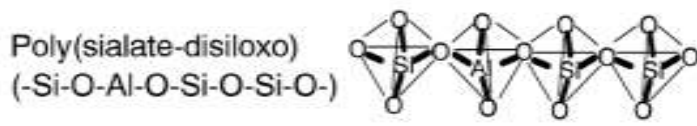

Gambar 2. Tipe Golongan Polysiliate [5]

\subsection{Mortar Geopolimer Abu Terbang Hybrid}

Mortar geopolimer abu terbang hybrid dibuat dengan campuran antara agregat halus, air dan bahan pengikat yang dihasilkan dari reaksi polimerisasi antara alkali aktivator dengan silika dan alumina dari limbah abu terbang serta penggunaan semen Portland sebagai campuran.

Menurut García-lodeiro \& Fernández-jiménez [13] geopolimer hybrid menggunakan antara 20-30\% semen Portland dan 70-80\% abu terbang yang diaktifkan dengan larutan alkali $(\mathrm{NaOH})$ konsentrasi moderate (sedang) serta dilakukan perawatan di udara pada suhu ruang $\left(25^{\circ} \mathrm{C}\right)$. Sedangkan, geopolimer menggunakan $100 \%$ abu terbang dan tidak menggunakan semen Portland yang diaktifkan dengan larutan alkali $(\mathrm{NaOH})$ konsentrasi strong (kuat) serta dilakukan perawatan pada suhu tinggi $\left(85^{\circ} \mathrm{C}\right)$.

\subsection{Material Penyusun Mortar Geopolimer Hybrid 2.4.1 Agregat Halus}

Agregat halus atau pasir memiliki berbagai macam jenis. Salah satunya adalah pasir alami yang berasal dari sungai atau hasil pemecahan batu. Kualitas agregat halus berpengaruh terhadap kualitas beton. Sifat-sifat yang signifikan pada agregat halus adalah kadar air, penyerapan air, kepadatan, dan kandungan organik memberikan pengaruh terhadap kekuatan serta ketahanan mortar. Agregat halus merupakan agregat yang ukuran butirnya lebih kecil dari ayakan No. 4 (4,75 mm) dan lebih besar dari ayakan No. $200(0,075 \mathrm{~mm})$ berdasarkan SNI 031968-1990 [14].

\subsubsection{Abu Terbang}

Abu terbang adalah limbah hasil pembakaran batu bara pada Pembangkit Listrik Tenaga Uap (PLTU). Pembakaran batu bara menghasilkan sekitar $80-90 \%$ total jumlah abu terbang dan 10-20\% berupa abu dasar. Abu terbang disebut bahan anorganik yang terbentuk dari mineral karena proses pembakaran dan berbentuk partikel halus amorf [15]. Abu terbang memiliki partikel yang lolos ayakan No. $100(0,15 \mathrm{~mm})$ dan bersifat pozzolanik karena mengandung silika ( $\mathrm{Si}$ ) dan alumina $(\mathrm{Al})$, tetapi sedikit mengandung kalsium $(\mathrm{Ca})$.

Berdasarkan ASTM C-618 2005 [3], abu terbang ada tiga kelas, yaitu kelas $\mathrm{C}, \mathrm{N}$ dan $\mathrm{F}$. Abu terbang kelas $\mathrm{C}$ memiliki jumlah kandungan $\mathrm{SiO}_{2}+\mathrm{Al}_{2} \mathrm{O}_{3}+\mathrm{Fe}_{2} \mathrm{O}_{3}$ minimal 50\% dan kandungan $\mathrm{CaO}$ lebih dari $10 \%$. Abu terbang kelas $\mathrm{N}$ memiliki jumlah kandungan $\mathrm{SiO}_{2}+\mathrm{Al}_{2} \mathrm{O}_{3}$ $+\mathrm{Fe}_{2} \mathrm{O}_{3}$ minimal $70 \%$ dan kandungan $\mathrm{CaO}$ lebih dari $10 \%$. Sedangkan, abu terbang kelas $\mathrm{F}$ memiliki jumlah kandungan $\mathrm{SiO}_{2}+\mathrm{Al}_{2} \mathrm{O}_{3}+\mathrm{Fe}_{2} \mathrm{O}_{3}$ minimal $70 \%$ dan kandungan $\mathrm{CaO}$ kurang dari $10 \%$. Abu terbang kelas $\mathrm{F}$ adalah abu terbang rendah kalsium dengan kandungan $\mathrm{CaO}$ kurang dari $10 \%$. Oleh karena itu, abu terbang kelas $\mathrm{F}$ cocok untuk dibuat geopolimer karena mengandung silika dan alumina tinggi serta kalsium rendah sehingga dapat bereaksi baik dengan alkali membentuk ikatan polimerisasi [16].

\subsubsection{Semen Portland}

Semen Portland merupakan semen yang dibuat dengan cara menghancurkan terak semen sehingga berbentuk serbuk halus dan ditambah mineral dari kalsium, alumina dan silikat [17]. Adapun bahan pembentuk semen Portland adalah kalsium $(\mathrm{CaO})$ dari batu kapur, silikat $\left(\mathrm{SiO}_{2}\right)$ dari tanah lempung dan alumina $\left(\mathrm{Al}_{2} \mathrm{O}_{3}\right)$ dari tanah lempung.

Berdasarkan ASTM C-150 2014 [17] ada beberapa jenis semen Portland. Salah satunya adalah Ordinary Portland Cement (OPC) dan Portland Composite Cement (PCC). OPC adalah semen Portland tipe I yang digunakan untuk konstruksi umum dan tidak memerlukan persyaratan khusus, yaitu tidak tahan sulfat, tidak tahan panas hidrasi, terbuat dari banyak kalsium dan sedikit bahan tambah, tetapi memiliki kekuatan awal lebih cepat. Sedangkan, PCC merupakan semen yang digunakan 
untuk keperluan konstruksi umum, tetapi lebih tahan sulfat dan asam sedang serta lebih kedap air.

\subsubsection{Air}

Air merupakan komponen penting dalam pembuatan mortar untuk proses hidrasi, reaksi kimiawi dengan semen dan sebagai pelumas pada campuran mortar agar mudah pengerjaannya. Pada umumnya, air yang digunakan adalah aquades. Berdasarkan SNI 28472013 [18], standar air yang digunakan pada campuran mortar adalah air dengan $\mathrm{pH}$ normal $=7$, tidak mengandung senyawa-senyawa yang tercemar, tidak mengandung ion klorida $>0,5 \mathrm{gr} / \mathrm{l}$ dan tidak mengandung senyawa sulfat $>1 \mathrm{gr} / \mathrm{l}$.

Jumlah air terlalu banyak menyebabkan gelembung udara setelah proses hidrasi selesai. Namun, apabila jumlah air terlalu sedikit menyebabkan proses hidrasi tidak selesai. Oleh karena itu, intensitas penggunaan air harus sesuai dengan target kekuatan yang diinginkan.

\subsubsection{Larutan Alkali Aktivator}

Reaksi polimerisasi yang terjadi pada geopolimer berasal dari larutan alkali aktivator. Larutan alkali aktivator merupakan campuran sodium silikat $\left(\mathrm{Na}_{2} \mathrm{SiO}_{3}\right)$ dan sodium hidroksida $(\mathrm{NaOH})$. Larutan aktivator sangat berpengaruh untuk menghasilkan kekuatan yang terbaik sehingga diperlukan kombinasi yang sesuai [19]. Sodium silikat berfungsi sebagai katalis untuk meningkatkan kecepatan reaksi polimerik dan sebagai perekat antara material lain sehingga membantu dalam pembentukan pasta mortar. Sedangkan, sodium hidroksida berfungsi untuk mereaksikan silika dan alumina dari abu terbang sehingga dihasilkan ikatan polimerik yang kuat [20].

Sodium hidroksida secara alami berbentuk padatan dan biasanya tersedia dalam bentuk serpihan, butiran ataupun larutan. Sodium hidroksida juga larut dengan cepat di dalam air dan melepaskan panas ketika dilarutkan. Sedangkan, sodium silikat dikenal dengan natrium metasilicate (waterglass). Zat ini berbentuk kristal yang dapat larut dalam air menghasilkan larutan alkali aktivator. Perbandingan antara sodium silikat dan sodium hidroksida pada suatu larutan alkali aktivator disebut modulus aktivator (Ms).

\subsubsection{Superplasticizer}

Superplasticizier adalah bahan tambah yang digunakan untuk meningkatkan kemudahan dalam pengerjaan (workability). Penggunaan superplasticizier juga berguna untuk mengurangi intensitas air yang digunakan untuk membuat mortar dengan rencana mutu tertentu. Selain itu, superplasticizier berguna untuk membuat mortar tanpa terjadinya pemisahan (segregasi/ bleeding) dengan jumlah air yang besar [21]. Salah satu contoh superplasticizer adalah sikament $N N$.

\subsection{Pengujian Mortar Geopolimer Hybrid \\ 2.5.1 Kuat Tekan}

Berdasarkan SNI 03-6825-2002 [10], kuat tekan mortar adalah beban maksimum dengan satuan luas benda uji mortar berbentuk kubus dengan ukuran dan umur tertentu. Ukuran mortar umumnya adalah kubus kecil dengan dimensi sisi $5 \times 5 \times 5 \mathrm{~cm}$. Kuat tekan mortar dihitung dengan menggunakan rumus sebagai berikut.

$$
\sigma_{\mathrm{m}}=\mathrm{P} / \mathrm{A}
$$

dengan:

$\sigma_{\mathrm{m}} \quad=$ kuat tekan mortar $(\mathrm{MPa})$

$\mathrm{P} \quad=$ beban maksimum $(\mathrm{N})$

A $\quad=$ luas penampang yang dibebani $\left(\mathrm{mm}^{2}\right)$

\section{METODE PENELITIAN}

\subsection{Persiapan Material Penelitian \\ 3.1.1 Agregat Halus}

Agregat halus yang digunakan adalah pasir dari Teratak Buluh, Kampar. Agregat halus dengan ukuran butirnya lebih kecil dari ayakan No. 4 (4,75 mm) dan lebih besar dari ayakan No. 200 (0,075 mm) berdasarkan SNI 03-1968-1990 [14]. Pengujian karakteristik agregat halus meliputi berat volume, berat jenis, kadar air, analisa saringan agregat, kadar organik dan kadar lumpur. Karakteristik agregat halus diuji di Laboratorium Teknologi Bahan, Teknik Sipil, Universitas Riau.

\subsubsection{Abu Terbang}

Abu terbang diperoleh dari PLTU Ombilin, Padang. Sebelum menggunakannya, abu terbang terlebih dahulu dikeringkan di dalam oven. Setelah dikeringkan, abu terbang kemudian diayak dengan saringan No. $100(0,15$ $\mathrm{mm})$. Pengujian karakteristik abu terbang dilakukan di PT. Sucofindo, Pekanbaru berdasarkan ASTM C-618 2005 [3].

\subsubsection{Semen Portland}

Semen yang digunakan adalah semen tipe I OPC (Ordinary Portland Cement) dan PCC (Portland Composite Cement). Pengujian karakterstik semen dilakukan PT. Semen Padang berdasarkan ASTM C-150 2014 dapat dilihat pada Tabel 2 berikut.

Tabel 2. Karakteristik Semen Portland [22]

\begin{tabular}{lccc}
\hline \multirow{2}{*}{ Parameter } & \multirow{2}{*}{ Satuan } & \multicolumn{2}{c}{ Semen Portland } \\
\cline { 3 - 4 } & & OPC & PCC \\
\hline $\mathrm{SiO}_{2}$ & $\%$ & 20,92 & 23,04 \\
$\mathrm{Al}_{2} \mathrm{O}_{3}$ & $\%$ & 5,49 & 7,40 \\
$\mathrm{Fe}_{2} \mathrm{O}_{3}$ & $\%$ & 3,78 & 3,36 \\
$\mathrm{CaO}$ & $\%$ & 65,21 & 57,38 \\
\hline
\end{tabular}




\subsubsection{Air}

Air yang digunakan adalah aquades dari Pekanbaru dengan $\mathrm{pH}$ normal $(\mathrm{pH}=7$ ) sesuai SNI 7974-2013 [18]. Air tersebut telah memenuhi standar air yang digunakan untuk membuat mortar.

\subsubsection{Larutan Alkali Aktivator}

Larutan alkali aktivator yang digunakan adalah sodium silikat $\left(\mathrm{Na}_{2} \mathrm{SiO}_{3}\right)$ dan sodium hidroksida $(\mathrm{NaOH})$. Perbandingan antara sodium silikat dan sodium hidroksida atau modulus aktivator (Ms) digunakan untuk perencanaan campuran mortar.

Sodium hidroksida berbentuk padatan dilarutkan di dalam air sehingga menjadi larutan sesuai dengan kemolaran yang diinginkan. Sedangkan, sodium silikat berbentuk larutan memiliki mol rasio 2,26 yang terdiri dari senyawa solid $\mathrm{SiO}_{2}$ dan $\mathrm{Na}_{2} \mathrm{O}$ sebanyak $31,75 \%$ dan $14,51 \%$ serta total sebanyak 46,26\%. Pengujian karakteristik sodium silikat dari PT. Sinar Sakti Kimia, Jawa Tengah dapat dilihat pada Tabel 3 berikut.

Tabel 3. Karakteristik dari Sodium Silikat

\begin{tabular}{ccc}
\hline Parameter & Satuan & Hasil analisis \\
\hline $\mathrm{SiO}_{2}$ & $\%$ & 31,75 \\
$\mathrm{Na}_{2} \mathrm{O}$ & $\%$ & 14,51 \\
Total solid & $\%$ & 46,26 \\
Mol ratio & & 2,26 \\
Density & $\mathrm{gr} / \mathrm{mL}$ & 1,56 \\
Baume & $\mathrm{Be}$ & 52 \\
\hline
\end{tabular}

\subsubsection{Superplasticizer}

Superplasticizer yang digunakan berasal dari PT. Sika Indonesia, yaitu sikament NN. Senyawa kimia pada sikament $N N$ adalah napthtalene formaldehyde sulfonate dengan densitas 1,17 hingga $1,19 \mathrm{~kg} / \mathrm{l}$.

\subsection{Pengujian Karakteristik Material}

Karakteristik material diuji untuk mengetahui sifat material yang digunakan. Pengujian karakteristik dilakukan pada agregat halus dan abu terbang yang digunakan untuk membuat mortar. Karakteristik agregat halus diuji di Laboratorium Teknologi Bahan, Teknik Sipil, Universitas Riau. Sedangkan, karakteristik abu terbang diuji di PT. Sucofindo, Pekanbaru.

\subsection{Perencanaan Campuran Benda Uji}

Perencanaan campuran mortar geopolimer abu terbang hybrid yang tepat didapatkan dari hasil pengujian karakteristik material. Campuran mortar geopolimer hybrid terdiri dari agregat halus, abu terbang, semen Portland, air, larutan alkali aktivator dan superplasticizer.

Material penyusun mortar geopolimer hybrid disiapkan dengan variasi konsentrasi $\mathrm{NaOH} 10 \mathrm{M}$ dan $12 \mathrm{M}$, nilai rasio modulus aktivator $\left(\mathrm{Na}_{2} \mathrm{SiO}_{3} / \mathrm{NaOH}\right) 1,5$ dan 2,5, penggantian sebagian abu terbang dengan semen sebesar $10 \%$ dan $15 \%$ serta tipe semen yang digunakan adalah OPC dan PCC. Perencanaan campuran mortar dapat dilihat pada Tabel 4 berikut.
Tabel 4. Perencanaan Campuran Mortar

\begin{tabular}{cccccc}
\hline & $\begin{array}{c}\text { NaOH } \\
(\mathrm{M})\end{array}$ & $\begin{array}{c}\text { Rasio } \\
\text { Ms }\end{array}$ & $\begin{array}{c}\% \\
\text { Semen }\end{array}$ & $\begin{array}{c}\text { Tipe } \\
\text { Semen }\end{array}$ & $\begin{array}{c}\% \text { Abu } \\
\text { Terbang }\end{array}$ \\
\hline \multirow{4}{*}{ Mix 1} & 10 & 1,5 & 10 & OPC & 90 \\
& 10 & 1,5 & 10 & PCC & 90 \\
& 10 & 1,5 & 15 & OPC & 85 \\
& 10 & 1,5 & 15 & PCC & 85 \\
\cline { 2 - 6 } Mix 2 & 12 & 1,5 & 10 & OPC & 90 \\
& 12 & 1,5 & 10 & PCC & 90 \\
& 12 & 1,5 & 15 & OPC & 85 \\
\cline { 2 - 6 } Mix 3 & 12 & 1,5 & 15 & PCC & 85 \\
& 10 & 2,5 & 10 & OPC & 90 \\
& 10 & 2,5 & 10 & PCC & 90 \\
& 10 & 2,5 & 15 & OPC & 85 \\
\hline
\end{tabular}

Mix 1 dilakukan dengan penggantian $10 \%$ dan $15 \%$ semen OPC atau PCC yang akan digunakan pada mortar geopolimer abu terbang hybrid. Pada setiap benda uji untuk mix ini, $\mathrm{NaOH}$ yang digunakan adalah $10 \mathrm{M}$ dan rasio modulus aktivator (Ms) sebesar 1,5. Pada mix 2 dilakukan dengan konsentrasi $\mathrm{NaOH}$ 12M. Pada setiap benda uji untuk mix ini, rasio modulus aktivator (Ms) sebesar 1,5 serta semen OPC atau PCC yang akan digunakan sebagai penggantian sebesar $10 \%$ dan $15 \%$. Sedangkan, mix 3 dilakukan dengan rasio modulus aktivator (Ms) 2,5. Pada setiap benda uji untuk mix ini, konsentrasi $\mathrm{NaOH}$ sebesar $10 \mathrm{M}$ serta semen OPC atau PCC yang akan digunakan sebagai penggantian sebesar $10 \%$ dan $15 \%$. Kuat tekan diuji pada umur 7 dan 28 hari dengan perawatan suhu ruang.

\subsection{Pelaksanaan Pembuatan Benda Uji}

Pencampuran mortar geopolimer abu terbang hybrid dilakukan menggunakan alat mixer mortar di Laboratorium Teknologi Bahan, Teknik Sipil, Universitas Riau. Alat tersebut digunakan untuk mengurangi ketidakmerataan berbagai bahan campuran selama pengadukan. Campuran agregat halus, abu terbang, semen Portland, larutan alkali aktivator dan superplasticizer diaduk selama lima menit, kemudian dicetak dalam mould mortar. Setiap variasi mortar geopolimer abu terbang hybrid berjumlah tiga benda uji pada masing-masing umur pengujian mortar dapai dilihat pada Tabel 5 berikut.

Tabel 5. Pembuatan Benda Uji Mortar

\begin{tabular}{ccccc}
\hline Mix no. & $\begin{array}{c}\text { Variasi larutan } \\
\text { aktivator }\end{array}$ & \multicolumn{2}{c}{$\begin{array}{c}\text { Persentase semen } \\
(\%)\end{array}$} & $\begin{array}{c}\text { Umur } \\
\text { Pengujian } \\
\text { (hari) }\end{array}$ \\
\cline { 3 - 4 } 1. & $\begin{array}{c}\mathrm{NaOH}=10 \mathrm{M} \\
\mathrm{Ms}=1,5\end{array}$ & $10 ; 15$ & $10 ; 15$ & $7 ; 28$ \\
2. & $\begin{array}{c}\mathrm{NaOH}=12 \mathrm{M} \\
\mathrm{Ms}=1,5\end{array}$ & $10 ; 15$ & $10 ; 15$ & $7 ; 28$ \\
3. & $\begin{array}{c}\mathrm{NaOH}=10 \mathrm{M} \\
\mathrm{Ms}=2,5\end{array}$ & $10 ; 15$ & $10 ; 15$ & $7 ; 28$ \\
\hline
\end{tabular}




\subsection{Rest Periode dan Perawatan Suhu Ruang}

Reaksi polimerisasi berlangsung sekitar 0 sampai 5 hari. Oleh karena itu, diperlukan rest periode agar benda uji mortar menyatu dan mengeras sebelum dibuka cetakan. Berdasarkan penelitian Djwantoro Hardjito \& Rangan [16], rest periode optimum geopolimer terjadi selama 3 hari. Setelah 3 hari, campuran geopolimer telah menyatu dan dapat dilepas dari catakan. Selanjutnya, perawatan benda uji mortar dilakukan pada suhu ruang sekitar $24-27^{\circ} \mathrm{C}$ selama 7 hari dan 28 hari.

\subsection{Pelaksanaan Pengujian Benda Uji}

Pelaksaan pengujian benda uji dilakukan untuk menentukan kekuatan dan kualitas benda uji. Pengujian yang dilakukan berupa pengujian sifat mekanik, yaitu kuat tekan. Kuat tekan diuji pada umur 7 hari dan 28 hari perawatan suhu ruang. Pengujian kuat tekan mortar berdasarkan SNI 03-6825-2002 [10] bertujuan untuk mengetahui gaya maksimum per satuan luas benda uji mortar berbentuk kubus dengan ukuran $5 \times 5 \times 5 \mathrm{~cm}$.

Prosedur pengujian dimulai setelah 7 hari dan 28 hari perawatan suhu ruang, kemudian menimbangnya. Selanjutnya, meletakkan benda uji sesuai posisi pada kerangka alat uji tekan mortar. Catat beban maksimum yang terjadi selama pengujian dan hitung kuat tekan beton, yaitu beban maksimum per satuan luas permukaan mortar.

\section{HASIL DAN PEMBAHASAN}

\subsection{Hasil Pengujian Karakteristik Agregat Halus}

Karakteristik agregat halus ini diuji di Laboratorium Teknologi Bahan, Teknik Sipil, Universitas Riau. Pengujian ini bertujuan untuk mengetahui karakteristik agregat yang digunakan sebagai material penyusun beton geopolimer hybrid. Agregat halus berasal dari Sungai Teratak Buluh, Kampar. Hasil pengujian karakteristik agregat halus dapat dilihat pada Tabel 6 berikut.

Tabel 6. Hasil Pengujian Karakteristik Agregat Halus

\begin{tabular}{clccc}
\hline No. & \multicolumn{1}{c}{ Jenis pengujian } & Hasil & Spesifikasi & Satuan \\
\hline 1. & Modulus kehalusan & 2,94 & $1,50-3,80$ & - \\
2. & Kadar air & 2,20 & $3-5$ & $\%$ \\
& $\begin{array}{l}\text { Berat jenis } \\
\text { 3. }\end{array}$ & & & \\
aulk Specific & 2,65 & $2,56-2,86$ & - \\
& $\quad$ Gravity on SSD & & & $\%$ \\
& b. Absorption & 2,46 & $2-7$ & $\%$ \\
& Berat volume & & & \\
4. & a. Keadaan padat & 1,72 & $1,40-1,90$ & $\mathrm{gr} / \mathrm{cm}^{3}$ \\
& b. Keadaan gembur & 1,63 & $1,40-1,90$ & $\mathrm{gr} / \mathrm{cm}^{3}$ \\
5. & Kadar lumpur & 0,85 & $<5$ & $\%$ \\
6. & Kadar organik & No. 1 & $<$ No. 3 & - \\
\hline
\end{tabular}

Pada Tabel 6 dapat dilihat hasil pengujian karakteristik agregat halus yang digunakan memiliki nilai modulus kehalusan sebesar 2,94 yang memenuhi standar spesifikasi, yaitu 1,50-3,80. Nilai kadar air diperoleh sebesar 2,20\% belum memenuhi standar spesifikasi yang disyaratkan, yaitu 3-5\%. Hal tersebut dikarenakan agregat halus dalam kondisi yang kering. Nilai bulk specific gravity on SSD dan absorption yang diperoleh sebesar 2,65 dan $2,46 \%$. Nilai bulk specific gravity on SSD telah memenuhi standar spesifikasi yang disyaratkan, yaitu 2,58-2,86 dan absorption juga telah memenuhi standar spesifikasi, yaitu 2-7\%. Nilai berat volume yang diperoleh sebesar $1,72 \mathrm{gr} / \mathrm{cm}^{3}$ dalam keadaan padat dan $1,63 \mathrm{gr} / \mathrm{cm}^{3}$ dalam keadaan gembur. Nilai berat volume dalam kondisi padat dan berat volume dalam kondisi gembur telah memenuhi standar spesifikasi yang disyaratkan, yaitu $1,40-190 \mathrm{gr} / \mathrm{cm}^{3}$. Selain itu, agregat halus ini memiliki nilai kadar lumpur sebesar 0,85\% telah memenuhi standar spesifikasi, yaitu $<5 \%$. Kadar organik pada agregat halus ini diperoleh warna No.1. Warna ini telah memenuhi standar spesifikasi, yaitu <No.3. Secara keseluruhan, agregat halus ini memiliki kualitas baik karena telah memenuhi standar spesifikasi, tetapi jumlah kadar air tergolong kecil karena dalam kondisi yang kering.

\subsection{Hasil Pengujian Karakteristik Abu Terbang}

Pengujian karakteristik abu terbang pada penelitian ini dilakukan di PT. Sucofindo di Pekanbaru. Pengujian karakteristik abu terbang dilakukan untuk mengetahui komposisi unsur kimia yang terkandung di dalam abu terbang tersebut. Abu terbang diuji dalam kondisi kering dan lolos saringan No. 100 (0,15 mm). Abu terbang ini berasal dari PLTU Ombilin, Padang, Sumatera Barat. Hasil pengujian abu terbang dapat dilihat pada Tabel 7 berikut.

Tabel 7. Hasil Pengujian Karakteristik Abu Terbang

\begin{tabular}{ccc}
\hline Parameter uji & Satuan & Hasil analisa \\
\hline Loss on Ignition (LOI) & $\%$ & 18,98 \\
$\mathrm{SiO}_{2}$ & $\%$ & 59,25 \\
$\mathrm{Al}_{2} \mathrm{O}_{3}$ & $\%$ & 29,25 \\
$\mathrm{Fe}_{2} \mathrm{O}_{3}$ & $\%$ & 5,45 \\
$\mathrm{TiO}_{2}$ & $\%$ & 0,83 \\
$\mathrm{CaO}$ & $\%$ & 1,54 \\
$\mathrm{MgO}$ & $\%$ & 0,31 \\
$\mathrm{~K}_{2} \mathrm{O}$ & $\%$ & 2,23 \\
$\mathrm{Na}_{2} \mathrm{O}$ & $\%$ & 0,68 \\
$\mathrm{SO}_{3}$ & $\%$ & 0,29 \\
$\mathrm{P}_{2} \mathrm{O}_{5}$ & $\%$ & 0,04 \\
$\mathrm{MnO}_{2}$ & $\%$ & 0,01 \\
\hline
\end{tabular}

Berdasarkan hasil pengujian karakteristik kimia abu terbang PLTU Ombilin, Padang, Sumatera Barat didapat abu terbang mengandung $\mathrm{SiO}_{2}$ sebesar 59,25\%, $\mathrm{Al}_{2} \mathrm{O}_{3}$ sebesar 29,25\% dan $\mathrm{Fe}_{2} \mathrm{O}_{3}$ sebesar 5,45\%. Hasil ini menunjukkan abu terbang PLTU Ombilin tergolong kelas $\mathrm{F}$ karena $\mathrm{SiO}_{2}+\mathrm{Al}_{2} \mathrm{O}_{3}+\mathrm{Fe}_{2} \mathrm{O}_{3}>70 \%$ [3]. Abu terbang kelas $\mathrm{F}$ memiliki kalsium yang rendah dan dapat dimanfaatkan sebagai material geopolimer. Akan tetapi, abu terbang ini memiliki nilai LOI tinggi, yaitu 18,98\% yang melebihi standar ASTM maksimal 12\%. LOI merupakan kadar karbon yang tidak terbakar. Jumlah LOI 
tergantung dari operasi pembakaran dan penggilingan batu bara, semakin banyak jumlah LOI maka abu terbang kurang reaktif karena mengandung karbon yang dapat menghambat jalannya reaksi geopolimer [23].

\subsection{Hasil Pengujian Kuat Tekan}

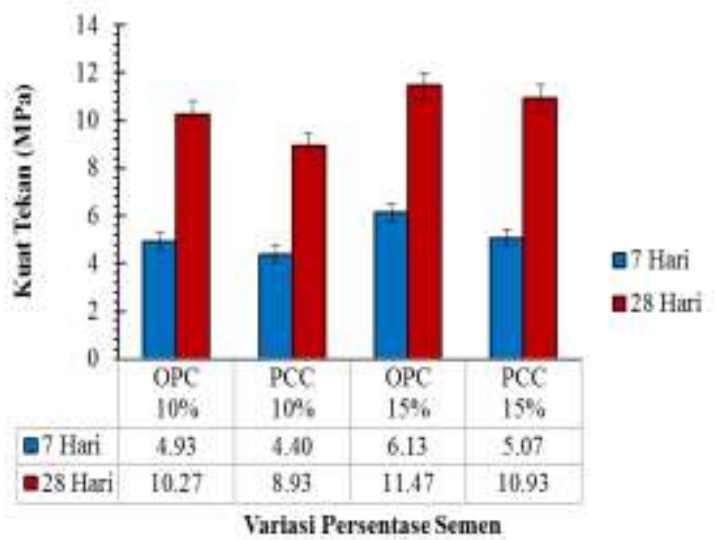

Gambar 3. Hasil Pengujian Kuat Tekan Mortar Berdasarkan Variasi Persentase Semen dengan $\mathrm{NaOH} 10 \mathrm{M}$ dan Ms 1,5

Pada Gambar 3 didapat hasil kuat tekan mortar geopolimer hybrid dengan variasi persentase semen menggunakan $\mathrm{NaOH} 10 \mathrm{M}$ dan $\mathrm{Ms}$ 1,5. Hasil kuat tekan meningkat dengan bertambahnya persentase OPC atau PCC yang digunakan. Pada umur 7 hari, didapat kuat tekan tertinggi pada mortar geopolimer hybrid OPC $15 \%$ dan PCC 15\% masing-masing, yaitu 6,13 MPa dan 5,07 MPa. Setelah umur 28 hari, didapat kuat tekan mortar tertinggi juga pada variasi persentase semen $15 \%$, yaitu mortar geopolimer hybrid OPC mencapai 11,47 MPa dan mortar geopolimer hybrid PCC mencapai 10,93 MPa. Namun, dapat dilihat kuat tekan mortar geopolimer hybrid menggunakan OPC memiliki hasil yang lebih tinggi dibandingkan menggunakan PCC. Hal ini diakibatkan kandungan $\mathrm{Ca}$ (kalsium) yang lebih banyak pada OPC dibandingkan PCC. Berdasarkan penelitian Pradana et al. [24] juga menunjukkan penggunaan OPC memiliki karakteristik kekuatan awal yang lebih tinggi dibandingkan dengan menggunakan PCC.

Gambar 4 menunjukkan hasil kuat tekan mortar geopolimer hybrid dengan variasi persentase semen menggunakan $\mathrm{NaOH} 12 \mathrm{M}$ dan $\mathrm{Ms}$ 1,5. Hasil kuat tekan juga meningkat dengan bertambahnya persentase OPC atau PCC yang digunakan sesuai dengan hasil mix 1. Pada umur 7 hari, didapat kuat tekan tertinggi pada mortar geopolimer hybrid OPC 15\% dan PCC 15\% masingmasing, yaitu 6,53 MPa dan 5,07 MPa. Setelah umur 28 hari, didapat kuat tekan mortar tertinggi juga pada variasi persentase semen $15 \%$, yaitu mortar geopolimer hybrid OPC mencapai 12,27 MPa dan mortar geopolimer hybrid PCC mencapai 11,07 MPa. Namun, dapat dilihat mortar geopolimer hybrid menggunakan $\mathrm{NaOH} 12 \mathrm{M}$ memiliki kuat tekan yang lebih tinggi dibandingkan mortar menggunakan $\mathrm{NaOH} 10 \mathrm{M}$ pada mix 1 . Hasil mix ini sesuai dengan penelitian [25] yang menunjukkan reaksi geopolimer dipengaruhi oleh kosentrasi $\mathrm{NaOH}$. Semakin meningkat konsentrasi $\mathrm{NaOH}$, maka semakin meningkatkan kekuatan geopolimer. Namun, jika konsentrasi $\mathrm{NaOH}$ berlebihan akan mengganggu proses reaksi sehingga ion $\mathrm{OH}$ - tidak efektif untuk meningkatkan kekuatan. Penelitian Bakri et al. [26] juga menunjukkan konsentrasi $\mathrm{NaOH}$ moderate (sedang) seperti $10 \mathrm{M}$ dan 12M mencapai kekuatan yang optimum daripada konsentrasi $\mathrm{NaOH}$ yang lain.

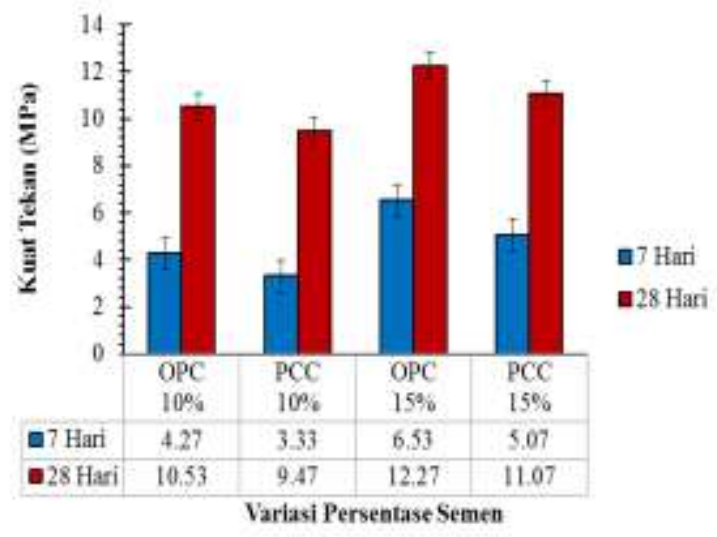

Gambar 4. Hasil Pengujian Kuat Tekan Mortar Berdasarkan

Variasi Persentase Semen dengan $\mathrm{NaOH} 12 \mathrm{M}$ dan Ms 1,5

Berdasarkan Gambar 5 didapat hasil kuat tekan mortar geopolimer hybrid dengan variasi persentase semen menggunakan $\mathrm{NaOH} 10 \mathrm{M}$ dan $\mathrm{Ms}$ 2,5. Hasil kuat tekan juga meningkat dengan bertambahnya persentase OPC atau PCC yang digunakan sesuai dengan hasil mix 1 dan 2. Pada umur 7 hari, didapat kuat tekan tertinggi pada mortar geopolimer hybrid OPC 15\% dan PCC $15 \%$ masing-masing, yaitu 8,27 MPa dan 6,27 MPa. Setelah umur 28 hari, didapat kuat tekan mortar tertinggi juga pada variasi persentase semen $15 \%$, yaitu mortar geopolimer hybrid OPC mencapai 13,33 MPa dan mortar geopolimer hybrid PCC mencapai 11,47 MPa. Namun, dapat dilihat mortar geopolimer hybrid menggunakan Ms 2,5 memiliki kuat tekan yang lebih tinggi dibandingkan mortar menggunakan Ms 1,5 pada mix 1 dan 2 . Peningkatan rasio modulus Ms akan meningkatkan kuantitas dari $\mathrm{Na}_{2} \mathrm{SiO}_{3}$ (sodium silikat). Rasio modulus perbandingan antara $\mathrm{Na}_{2} \mathrm{SiO}_{3} / \mathrm{NaOH}$ yang terlalu tinggi akan mengurangi kuantitas dari $\mathrm{NaOH}$ mengakibatkan kekuatan geopolimer menurun. Namun, begitu sebaliknya jika rasio modulus terlalu rendah akan meningkatkan kuantitas dari $\mathrm{NaOH}$ sehingga mengakibatkan produksi ion OH- yang berlebihan. Berdasarkan penelitian Joseph \& Mathew [27] juga menunjukkan kekuatan optimum campuran geopolimer menggunakan rasio modulus Ms moderate (sedang) seperti 2 dan 2,5. 


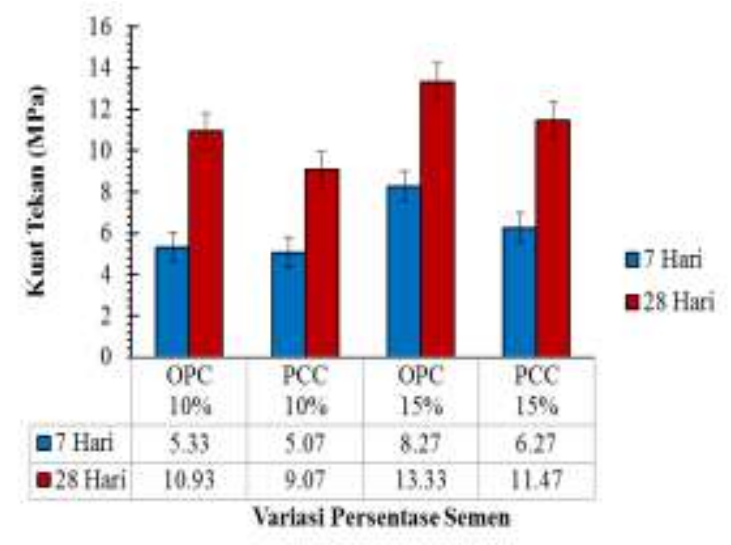

Gambar 5. Hasil Pengujian Kuat Tekan Mortar Berdasarkan Variasi Persentase Semen dengan $\mathrm{NaOH}$ 10M dan Ms 2,5

\section{KESIMPULAN DAN SARAN}

\subsection{Kesimpulan}

Berdasarkan hasil pengujian yang dilakukan terhadap penelitian mortar geopolimer abu terbang hybrid maka didapat kesimpulan sebagai berikut.

1. Abu terbang dari PLTU Ombilin Padang bersifat rendah kalsium dan tinggi silika. Abu terbang PLTU Ombilin tergolong kelas $\mathrm{F}$ karena $\mathrm{SiO}_{2}+\mathrm{Al}_{2} \mathrm{O}_{3}+$ $\mathrm{Fe}_{2} \mathrm{O}_{3}>70 \%$. Oleh karena itu, berpotensi digunakan untuk material geopolimer.

2. Agregat halus berasal dari Sungai Teratak Buluh, Kabupaten Kampar berkarakteristik baik dan memenuhi standar yang telah ditetapkan.

3. Hasil pengujian kuat tekan mortar geopolimer abu terbang hybrid menggunakan Portland Composite Cement (PCC) memiliki kekuatan yang lebih rendah dibandingkan menggunakan Ordinary Portland Cement (OPC). Mortar geopolimer hybrid dengan penggantian $15 \%$ semen lebih tinggi dibandingkan dengan penggantian $10 \%$ semen. Hasil optimum pada mortar geopolimer hybrid OPC dengan penggantian $15 \%$ umur 7 hari dan 28 hari, yaitu 6,13 $\mathrm{MPa}$ dan 11,47 MPa. Sedangkan, mortar geopolimer hybrid PCC dengan penggantian $15 \%$ umur 7 hari dan 28 hari, yaitu 5,07 MPa dan 10,93 MPa.

4. Hasil pengujian kuat tekan mortar geopolimer abu terbang hybrid menggunakan $\mathrm{NaOH} 12 \mathrm{M}$ memiliki kuat tekan yang lebih tinggi dibandingkan menggunakan $\mathrm{NaOH} 10 \mathrm{M}$. Namun, hasil optimum tetap pada mortar geopolimer hybrid OPC dengan penggantian $15 \%$ semen umur 7 hari dan 28 hari, yaitu 6,53 MPa dan 12,27 MPa. Sedangkan, pada mortar geopolimer hybrid PCC dengan penggantian $15 \%$ semen umur 7 hari dan 28 hari, yaitu 5,07 MPa dan 11,07 MPa.

5. Hasil pengujian kuat tekan mortar geopolimer abu terbang hybrid menggunakan rasio modulus Ms 2,5 memiliki kuat tekan yang lebih tinggi dibandingkan menggunakan rasio modulus Ms 1,5. Namun, hasil optimum tetap pada mortar geopolimer hybrid OPC dengan penggantian $15 \%$ semen umur 7 hari dan 28 hari, yaitu 8,27 MPa dan 13,33 MPa. Sedangkan, pada mortar geopolimer hybrid PCC dengan penggantian $15 \%$ semen umur 7 hari dan 28 hari, yaitu $6,27 \mathrm{MPa}$ dan 11,47 MPa.

6. Dapat disimpulkan dari seluruh hasil pengujian, kuat tekan optimum mortar geopolimer abu terbang hybrid adalah variasi $\mathrm{NaOH} 10 \mathrm{M}$, Ms 2,5 dan penggantian sebagian abu terbang dengan semen sebesar $15 \%$.

\subsection{Saran}

Saran untuk penelitian mortar geopolimer abu terbang hybrid ini adalah sebagai berikut.

1. Perlu diuji lebih lanjut hingga umur benda uji 91 hari bahkan 120 hari agar data yang dihasilkan lebih baik.

2. Masa perawatan suhu ruang sebaiknya menggunakan desikator agar suhu ruang tetap stabil.

\section{DAFTAR PUSTAKA}

[1] Peraturan Pemerintah No 101 Tahun 2014, "Pengelolaan limbah Bahan Berbahaya dan Beracun (B3)," 2014.

[2] Kementerian ESDM, "Laporan kinerja Kementerian ESDM 2016," 2016.

[3] ASTM C-618 2005, "Standard specification for coal fly ash and raw or calcined natural pozzolan for use," 2005.

[4] Julharmito, A. Fadli, and Drastinawati, "Pemanfaatan limbah abu terbang (fly ash) batubara sebagai bahan campuran beton geopolimer," JOM FTeknik, vol. 2, pp. 1-7, 2015.

[5] J. Davidovits, "Properties of geopolymer cements," Sci. Res. Inst. Bind. Mater., pp. 119, 1994.

[6] G. Habert, J. B. D’Espinose De Lacaillerie, and N. Roussel, "An environmental evaluation of geopolymer based concrete production: Reviewing current research trends," J. Clean. Prod., vol. 19, pp. 12291238, 2011.

[7] P. Nath, P. Kumar, and V. B. Rangan, "Early age properties of low-calcium fly ash geopolymer concrete suitable for ambient curing," Procedia Eng., vol. 125, pp. 601607, 2015.

[8] J. M. Mejía, E. Rodríguez, R. Mejía De Gutiérrez, and N. Gallego, "Preparation and characterization of a hybrid alkaline binder based on a fly ash with no commercial value," J. Clean. Prod., vol. 104, no. June, pp. 346-352, 2015.

[9] I. García-lodeiro, S. Donatello, A. Fernández-jiménez, and Á. Palomo, "Hydration of hybrid alkaline cement containing a very large proportion of fly ash: hydration of hybrid alkaline cement 
containing a very large proportion of fly ash," Materials (Basel)., no. July, 2016.

[10] SNI 03-6825-2002, "Metode pengujian kekuatan tekan mortar semen Portland untuk pekerjaan sipil," 2002.

[11] R. Manuahe, M. D. J. Sumajouw, and R. S. Windah, "Kuat tekan beton geopolimer berbahan dasar abu terbang (fly ash)," $J$. Sipil Statik, vol. 2, pp. 277-282, 2014.

[12] A. Fernandez-Jimenez, A. Palomo, and M. Criado, "Microstructure development of alkali-activated fly ash cement: a descriptive model," vol. 35, pp. 1204-1209, 2005.

[13] I. Garcia-Lodeiro, A. Fernández-Jimenez, and A. Palomo, "Cements with a low clinker content: versatile use of raw materials," $J$. Sustain. Cem. Mater., vol. 4, no. June, pp. 37-41, 2015.

[14] SNI 03-1968-1990, "Metode pengujian tentang analisis saringan agregat halus dan kasar," 1990.

[15] M. Munir, "Pemanfaatan abu batubara (fly ash) untuk hollow block yang bermutu dan aman bagi lingkungan," Surabaya, 2008.

[16] D. Hardjito and B. V Rangan, "Development and properties of low-calcium fly ash-based geopolymer concrete," 2005.

[17] ASTM C-150 2014, "Standard specification for Portland cement," 2014.

[18] SNI 7974-2013, "Spesifikasi air pencampur yang digunakan dalam produksi beton semen hidraulis," 2013.

[19] L. N. Assi, E. Eddie, M. K. Elbatanouny, and P. Ziehl, "Investigation of early compressive strength of fly ash-based geopolymer concrete," Constr. Build. Mater., vol. 112, pp. 807-815, 2016.

[20] H. Kasyanto, "Tinjauan kuat tekan geopolimer berbahan dasar fly ash dengan aktivator sodium hidroksida dan sodium silikat," 2012.

[21] R. I. A. Utami and B. Herbudiman, "Efek tipe superplasticizer terhadap sifat beton segar dan beton keras pada beton geopolimer berbasis fly ash," vol. 3, pp. 1-12, 2017.

[22] I. M. A. K. Salain, "Karakteristik beton semen Portland," Teknol. dan Kejuru., vol. 32, pp. 63-70, 2009.

[23] D. Hardjito, S. E. Wallah, D. M. J. Sumajouw, and B. V Rangan, "Factors influencing the compressive strength of fly ash-based geopolymer concrete," Civ. Eng. Dimens., vol. 6, pp. 88-93, 2007.

[24] T. Pradana, M. Olivia, and I. R. Sitompul, "Kuat tekan dan porositas beton semen OPC, PCC, dan OPC POFA di lingkungan gambut," Jom FTEKNIK, vol. 3, p. 8, 2016.

[25] S. Khan, N. Shafiq, and T. Ayub, "Effect of sodium hydroxide concentration on fresh properties and compressive strength of selfcompacting geopolymer concrete," vol. 8, pp. 44-56, 2013.

[26] Bakri, A. M. M. Al, H. Kamarudin, I. K. Bnhussain, M., Nizar, and A. R. Rafiza, "Microstructure of different $\mathrm{NaOH}$ molarity of fly ash- based green polymeric cement," Procedia Eng., vol. 3, pp. 44-49, 2011.

[27] B. Joseph and G. Mathew, "Influence of aggregate content on the behavior of fly ash based geopolymer concrete," Sci. Iran., vol. 19, pp. 1188-1194, 2012. 